\title{
Measurement of myofilament calcium in living cardiomyocytes using a targeted genetically encoded indicator
}

Paul Robinson ${ }^{1,2}$, Alexander J Sparrow ${ }^{1,2 \dagger}$, Connor N Broyles ${ }^{1,2 \dagger}$, Kolja Sievert ${ }^{1 \# a}$, Yu-Fen Chang $^{1,2 \# b}$, Frances A Brook ${ }^{1,2}$ Xiaoyu Zhang ${ }^{4}$, Hugh Watkins ${ }^{1,2,3}$, Yama A Abassi ${ }^{4}$, Michael A Geeves ${ }^{5}$, Charles Redwood ${ }^{1,2}$, Matthew J Daniels ${ }^{1,2,3,6,7 *}$

${ }^{1}$ Division of Cardiovascular Medicine, Radcliffe Department of Medicine, University of Oxford, Oxford, UK

${ }^{2}$ BHF Centre of Research Excellence, University of Oxford, Oxford, UK

${ }^{3}$ Department of Cardiology, Oxford University NHS Hospitals Trust, Oxford, UK

${ }^{4}$ ACEA Biosciences, Inc., San Diego, CA 92121, USA

${ }^{5}$ Department of Biosciences, University of Kent, Canterbury, UK

${ }^{6}$ BHF Centre of Regenerative Medicine, University of Oxford, Oxford, UK

${ }^{7}$ Department of Biotechnology, Graduate School of Engineering, Osaka University, Suita, Osaka, Japan

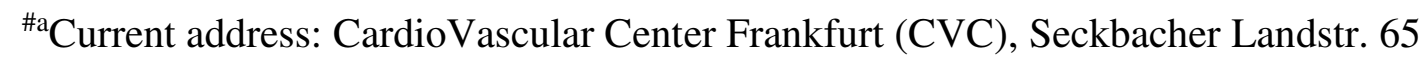
60389, Frankfurt, Germany

${ }^{\mathrm{Ab} C}$ Current address: Lumistar Biotechnology Inc., Zebulon Business Center 2F, No.467, Sec. 6, Zhongxiao E. Rd., Nangang Dist., Taipei City 115, Taiwan

*Corresponding author

†joint second authors

E-mail: matthew.daniels@ cardiov.ox.ac.uk (MJD) 


\begin{abstract}
:
Visualising when and where calcium appears and disappears in cardiomyocytes is a major goal of cardiovascular research. Surprisingly we find that the chemical dyes widely used for this purpose disrupt cell contractility, due at least in part due to direct inhibition of the acto-myosin ATPase required to generate force. In order to improve calcium detection methods, we have developed a genetically encoded indicator that sits within the myofilament to directly visualise the changes occurring at the sarcomere. This tool improves on established chemical dyes and untargeted genetically encoded indicators for analysing small molecule modulators of myofilament-based calcium signalling. Importantly this is achieved without any measurable change in contractile function.
\end{abstract}




\section{Introduction}

Calcium $\left(\mathrm{Ca}^{++}\right)$is the only physiologically occurring ion that activates contraction ${ }^{1}$. The process begins with voltage-dependent entry of extracellular $\mathrm{Ca}^{++}$that is amplified by massive intracellular $\mathrm{Ca}^{++}$release, principally from the sarcoplasmic reticulum (SR). The released $\mathrm{Ca}^{++}$ binds to Troponin $\mathrm{C}(\mathrm{TnC})$, promoting co-operative activation of the thin filament ${ }^{2,3}$ allowing the rigid actin scaffold to interact with the motor protein myosin enabling ATP dependent contraction $^{4,5}$. Relaxation occurs as $\mathrm{Ca}^{++}$is removed from the myofilament and repackaged into the SR, or pumped out of the cell, for subsequent cycles.

Protein architecture within the sarcomere is highly ordered and densely packed, producing a diffraction based striation pattern in unstained cells. Sarcomeric proteins are subject to point mutations and truncations in the common inherited heart diseases hypertrophic (HCM) and dilated (DCM) cardiomyopathy that change myofilament $\mathrm{Ca}^{++}$sensitivity and/or contractility $^{6,7}$. Modulators of contractility therefore represent potential therapies for these conditions, as well as the growing problem of heart failure ${ }^{8}$ in general. Importantly these should act without changes to total $\left[\mathrm{Ca}^{++}\right]$which is potentially pro-arrhythmic ${ }^{9}$. Therefore, to understand these diseases and identify such compounds, a need for myofilament $\left[\mathrm{Ca}^{++}\right]$and contractility assessment exists where ideally; measurement of one parameter does not alter the other.

Chemical dyes based on the non-fluorescent $\mathrm{Ca}^{++}$binder BAPTA such as fura2 ${ }^{10}$ or its colour variants are widely used to measure intracellular $\left[\mathrm{Ca}^{++}\right]$in cardiomyocytes. These are typically introduced into cells as acetoxymethyl (AM) esters, which increase membrane permeability and, after hydrolysis of the ester, lead to accumulation and concentration of the dye in the cardiomyocyte approximately 1000x the amount present in the medium. Adverse effects of these indicators have previously attributed to direct $\mathrm{Ca}^{++}$buffering and phototoxicity. 
However, recent work has highlighted direct inhibition of the $\mathrm{Na} / \mathrm{K}$ ATPase in many cell types by the BAPTA family of $\mathrm{Ca}^{++}$indicators ${ }^{11}$ which limits cell survival and may reduce ATP dependent force production. Indeed fura2-based impairment of contractility has previously been observed in isolated rat cardiac trabeculae ${ }^{12}$.

Genetically encoded calcium indicators (GECIs) offer an alternative strategy for $\left[\mathrm{Ca}^{++}\right]$ assessment ${ }^{13}$, with the possibility of subcellular targeting and lower $(\sim \mu \mathrm{M})$ expression levels. However, their uptake in cardiovascular research has been slow ${ }^{13}$ compared to neurobiology $\mathrm{y}^{14,15}$ as primary cardiomyocytes are difficult to transfect, and tend not to survive long enough in culture for gene expression and chromophore maturation. One highly desirable location for a $\mathrm{Ca}^{++}$indicator is in the sarcomere, where calcium regulates contractility. Myofilament specific probes however remain elusive, in part due to the concern that the bulky 30x40x70 $\AA$ adducts of the smallest GECIs ${ }^{16}$ may be poorly tolerated by the paracrystaline sarcomeric environment ${ }^{7,17}$ leading to perturbed function of the indicator, the fusion partner, or the cell.

Here we document the adverse effects on contractility of a number of chemical dyes widely used in cardiovascular research and go on to describe production and validation of a thin filament restricted GECI, RGECO-TnT. This novel $\mathrm{Ca}^{++}$sensor, not only avoids any disruption of contractility, but also provides additional mechanistic information about $\mathrm{Ca}^{++}$ handling in the myofilament compared to an unrestricted RGECO when drugs that target the myofilament are used.

\section{Results}

In a photometric system designed to minimise dye use and light exposure, we found the use of fura2 to measure $\left[\mathrm{Ca}^{++}\right]$in isolated ventricular adult guinea pig cardiomyocytes (vGPCMs) caused progressive inhibition of contractility across the dose range used in imaging 
studies (Figure 1a, b, Supplementary Figure 1). Impairment of fractional shortening may be caused by direct $\mathrm{Ca}^{++}$chelation (fura2 $K_{\mathrm{d}}=145 \mathrm{nM}$ ); as although the external concentration of fura2-AM ester is $1 \mu \mathrm{M}$, after ester hydrolysis fura2 becomes polar and cannot diffuse out of the cell leading to accumulation. Concentrations ranging between 0.1 and $40 \mathrm{mM}$ have been reported within cells ${ }^{18,19}$. Surprisingly, we also find inhibitory effects on whole-cell contractility with a chemical indicator of voltage, fluovolt ${ }^{20}$, and the sodium indicator $\mathrm{SBFI}^{21}$ (Figure 1c,d,e,f). These dyes do not bind $\mathrm{Ca}^{++}$but do require weak surfactant application with or without acetoxymethyl esterification, and thus these data suggest there may also be $\mathrm{Ca}^{++}$ independent inhibitory effects of chemical dyes.

In light of recent data showing direct inhibition of the $\mathrm{Na} / \mathrm{K}$ ATPase in many cell types by the BAPTA family of $\mathrm{Ca}^{++}$indicators ${ }^{11}$ we investigated the $\mathrm{Ca}^{++}$sensitivity of the actomyosin ATPase in vitro in the presence of fura2 to determine if $\mathrm{Ca}^{++}$sequestration or ATPase inhibition was the cause of contractile impairment. In addition to reduced $\mathrm{Ca}^{++}$ sensitivity, the maximum rate of ATP hydrolysis is also significantly depressed suggesting direct inhibition of the actomyosin ATPase itself (Figure 1g,h) raising the possibility that other ATPases aside from Na/K ATPase may also be vulnerable to chemical dyes. Therefore, mechanisms beyond simple $\mathrm{Ca}^{++}$buffering appear responsible for contractile impairment in dyes that do and do not have $\mathrm{Ca}^{++}$affinity. To test the additional role of phototoxicity we made use of the adherent properties of iPS-derived cardiomyocytes (iPS-CM), which also show a dose response inhibition of the number of cells able to visibly contract in the presence of fura2 (Supplementary Figure 2) limiting the utility of motion tracking contractility assessments ${ }^{22}$ with simultaneous fura $2 \mathrm{Ca}^{++}$imaging. Observer-independent impedance assessments of iPS$\mathrm{CM}$ contractility can be undertaken without extrinsic illumination ${ }^{23}$. We find that contractile suppression is detected in the presence of green-shifted calcium indicators on monolayer iPSCMs from a different vendor (Supplementary Figure 3); suggesting that neither UV light 
excitation phototoxicity occurring during fura2 imaging, nor cell singularisation, or indeed particular dyes or cell suppliers are required for this phenomenon. This suggests instead, that it may be due to direct biochemical effects of this group of compounds.

Protein based calcium indicators, the GECI's, have been iteratively developed alongside improvements in fluorescent proteins over the past two decades ${ }^{24}$. Currently in cardiovascular research we lack probes that function where calcium is stored (the SR) and its major functional target (the myofilament). In order to develop a thin filament-restricted GECI we screened fusion proteins of green fluorescent protein (GFP) with various troponin subunits to identify sites that preserve actomyosin ATPase regulation. In contrast to the other fusion proteins tested, we found that GFP conjugated to the N-terminus of Troponin-T does not disrupt $\mathrm{Ca}^{++}$regulation of the actomyosin ATPase (Supplementary Figure 4, Supplementary Table 1). Following this initial screen, the red calcium indicator $\mathrm{RGECO}^{25}$, previously applied to vGPCMs and iPS-CMs ${ }^{26}$, was conjugated to the N-terminus of Troponin-T (Figure 2a) and recombinant RGECO-TnT tested to show that it did not disrupt in vitro thin filament reconstitution (Supplementary Figure 5) or $\mathrm{Ca}^{++}$sensitivity of the actomyosin ATPase (Figure 2b). In vitro characterisation of the calcium indicator properties of RGECO-TnT showed a $K_{\mathrm{d}}$ of $764.5 \pm 17.6 \mathrm{nM}(\mathrm{RGECO}$ was $860.0 \pm 10.0 \mathrm{nM})$ under physiological $\mathrm{pH}^{27}$, temperature and magnesium concentration ${ }^{28}$ (Figure 2c, Supplementary Figure 6), with preservation of dynamic range and excitation/emission spectra (Figure 2d and e, Supplementary Table 2). At physiological temperature, $\mathrm{Ca}^{++}$on (at $10 \mu \mathrm{M}$ free $\mathrm{Ca}^{++} k_{\text {obs }} 16.7$ $\left.\mu \mathrm{M}^{-1} \mathrm{~s}^{-1}\right)$ and off $\left(k_{\text {off }}=16.9 \mathrm{~s}^{-1}\right)$ rates for RGECO-TnT were similar to RGECO (Supplementary Figure 7), and approximately twice those observed at $25^{\circ} \mathrm{C}$.

When RGECO-TnT is adenovirally expressed in vGPCMs (Figure 3a) or iPS-CMs (Figure 3b), in contrast to an unrestricted $\mathrm{RGECO}^{26}$, sarcomeric localisation without $\mathrm{M}$ line or Z-disc accumulation is observed. RGECO-TnT accumulates at levels similar to endogenous 
TnT (Figure 3c). With subcellular fractionation, we find that RGECO TnT shows exclusive accumulation at the sarcomere and is undetectable in the cytoplasm of vGPCMs (Supplementary Figure 8). Unlike fura2, which relaxes the resting sarcomere length and reduces sarcomeric shortening, the contractile parameters of both vGPCMs (Figure $3 \mathbf{d} \& \mathbf{e}$ ) and iPS-CMs (Supplementary Figure 2) appear unaffected by the presence of either RGECO or RGECO-TnT. $\mathrm{Ca}^{++}$transients are readily detected in electrically paced vGPCMs (Figure 3f) and iPS-CMs (Figure 3g), with reverse rate dependence. Dynamic range compression is apparent at higher pacing frequencies in vGPCM (Supplementary Figure 9) and iPS-CM (Supplementary Figure 10) as expected ${ }^{26,29}$. Spontaneous $\mathrm{Ca}^{++}$transients are also observed in iPS-CM (Supplementary movie 1). GECIs can be employed in combination with other indicators ${ }^{13,25}$ or optical control tools ${ }^{16,26}$; indeed RGECO-TnT can be used simultaneously with the cytoplasmic green $\mathrm{Ca}^{++}$indicator, $\mathrm{GGECO}^{25}$ in iPS-CMs (Supplementary Figure 11).

There is growing interest in the therapeutic use of small molecule modulators of myofilament contractility ${ }^{7,9,30,31}$. Importantly these should not affect $\mathrm{Ca}^{++}$handling, which may be pro-arrhythmic. To contrast the sensitivities and mechanistic insights of RGECO-TnT, RGECO and fura2, we investigated the effects of three drugs on $\mathrm{Ca}^{++}$handling and contractility. The myosin ATPase inhibitor MYK-461 ${ }^{30}$, levosimendan ${ }^{31}$ (a myofilament activator that stabilises the $\mathrm{Ca}^{++}$bound form of $\mathrm{TnC}$ ) and flecainide ${ }^{26}$, which does not target the myofilament but has complex effects on sodium $(\mathrm{SCN} 5 \mathrm{a})^{32}$, and potassium (hERG $)^{33}$ channels, and the ryanodine receptor $(\text { RyR2) })^{34,35}$ (Figure 4a, Supplementary Tables 3a, 4a, 5a). We find that the readouts of these probes are numerically and statistically different both in terms of their relative amplitudes and their timings. For example, MYK-461 reduces the relative fluorescence amplitude of RGECO $(0.852 \pm 0.035, \mathrm{p}=0.024)$ and more significantly using RGECO-TnT $(0.802 \pm 0.037 \mathrm{p}=<0.0004)$ whereas no change is seen with fura2 $(0.913 \pm 0.056 \mathrm{p}=0.124)$. RGECO-TnT also detects alterations to the $\mathrm{T}_{50}$ of $\mathrm{Ca}^{++}$binding for all drugs tested (MYK-461 
$=-0.031 \pm 0.002 \mathrm{sec} \mathrm{p}=<0.0001$, Levisomedan $=-0.016 \pm 0.002 \mathrm{p}=0.0001$, Flecanide $=-$ $0.008 \pm 0.002 \mathrm{p}=0.047$ ) whereas both RGECO and fura2 show no significant differences of this parameter. Importantly the GECI probes are free from the inhibition of the actomyosin ATPase shown by fura2, and allows contractile responses equivalent to unlabelled cells (Supplementary Figure 12, Supplementary Tables 3b, 4b, 5b), although these proteins will inevitably buffer intracellular $\mathrm{Ca}^{++}$. This remains true even when the indicator is concentrated in the myofilament itself where $\mathrm{Ca}^{++}$regulates contractility.

\section{Discussion}

Chemical dyes are widely used to highlight the activation and inactivation of excitable cells on millisecond timescales. There are more than 25,600 citations for the use of BAPTA derivative $\mathrm{Ca}^{++}$indicators to date ${ }^{11}$ but although problems like contractile inhibition ${ }^{12}$ and limited viability have hindered the field these effects were attributed to inevitable factors like calcium buffering and phototoxicity. Here we show that these mechanisms are less plausible than direct inhibition of the myosin ATPase itself, and in combination with a recent report documenting inhibition of the $\mathrm{Na} / \mathrm{K}$ ATPase ${ }^{11}$ this raises the possibility that these compounds may have a general action as ATPase inhibitors. By contrast, in spite of their mechanism of action as $\mathrm{Ca}^{++}$chelators GECI's do not have biochemically detectable effects on the actomyosin ATPase in vitro, or on contractility at the whole cell level even when positioned inside the myofilament. This is in agreement with a recent report of a cAMP indicator fused to the C-terminus of troponin I ( TnI) that gave correct myofilament localisation in cells and did not affect contractility ${ }^{36}$. We also tested the in vitro myofilament ATPase function of TnI as a smaller GFP fusion and found that typical $\mathrm{Ca}^{++}$dependence was lost so this tool was not developed further. The discrepancy between these observations may be explained by relative 
expression levels of the cAMP reporter in adult rat cardiomyocytes, which we assume (as this was not detailed in $^{36}$ ) will be lower than the $100 \%$ used in our in vitro assay. Alternatively, the larger FRET reporter may exert less steric hindrance on troponin complex formation and native ATPase activity than the GFP / GECIs used in this study.

Myofilament targeting appears to enhance reporter sensitivity to the underlying biology. For example, RGECO-TnT detects larger peak amplitude reductions or increases compared to the other indicators strategies when small molecules that act via the myofilament (MYK-461 and levosimendan) are used. This may result from subcellular proximity of the sensor to site of drug action. The effect of MYK-461 on $\mathrm{Ca}^{++}$handling was unexpected. Previous reports using fura 2 measurements in isolated rat cardiomyocytes showed no effect on $\mathrm{Ca}^{++}$transients with similar drug concentrations ${ }^{30}$. Although one explanation for this is the choice of indicator, other differences like duration of fura2 exposure, or different electrophysiology and $\mathrm{Ca}^{++}$ handling of rat cardiomyocytes compared to guinea pig cannot be excluded. When intracellular $\mathrm{Ca}^{++}$was modulated with flecainide, the unrestricted GECI sees no change in signal amplitude, in contrast the myofilament restricted GECI sees it fall. Together these data suggest that RGECO-TnT improves the sensitivity of detection of $\mathrm{Ca}^{++}$handling at the level of the myofilament when compared to fura2 or an unrestricted RGECO. These treatments also illustrate how the RGECO-TnT adds mechanistic information when assessing intracellular $\mathrm{Ca}^{++}$dynamics. Whilst all three sensors detect changes to $\mathrm{T}_{50}$ off times, neither fura2 nor unrestricted RGECO reported changes to $\mathrm{T}_{50}$ on rates. However, the myofilament restricted sensor appears able to identify these subtle changes.

Both GECIs offer significant advances during combined assessments of contractility. While the presence of GECIs had no significant effect on sarcomere shortening, fura2 loaded cells relax and contract less and demonstrate composite effects due to the action of both fura2 and drug being tested. For example, in indicator-free control vGPCMs, 250nM MYK-461 
increases resting sarcomere length by $\sim 0.1 \mu \mathrm{m}$. Either GECI strategy identifies this, but paradoxically the resting length shortens in cells also loaded with fura2. Similarly, although levosimendan treatment increases the resting diastolic sarcomere length in control cells, in the presence of fura2 it apparently decreases. These observations reveal the vulnerability for synergistic, or opposing, actions of the chemical dye on contractility to accentuate, or ameliorate, phenotypes induced by drugs in single cells. This may explain some of the difficulty generating these reagents, or their successful translation to the clinical environment.

In summary, we have identified a site within the contractile machinery that tolerates delivery of genetically encoded reporters into the heart of the myofilament without compromising the function of the cell, the indicator, or the fusion partner. This allows detection of the $\left[\mathrm{Ca}^{++}\right]$in the vicinity of the myofilament and permits simultaneous contractility measurements unaffected by the presence of the sensor, thus representing an improvement on the chemical dyes widely used in this field. This approach should also allow the targeting of other sensors to the myofilament to detect changes during development or disease.

\section{METHODS}

\section{Adenoviral Virus design and production}

Recombinant adenoviral constructs were created using the AdEasy XL recombination system (Agilent technologies) as previously described ${ }^{37}$. Briefly; RGECO and RGECO-TnT (Supplementary Figure 13) (sub-cloned using a BamH1 linker), were inserted into a shuttle vector, containing a CMV promoter. Viral DNA was produced via homologous recombination of the cloned shuttle vector, transfected and viral particles were scaled using the manufacturer's standard protocol. Viral titre was estimated by infection of serial dilutions of purified virus in a plate containing $\sim 2 \times 10^{6}$ unmodified HEK293 cells over a 48 hour period. Cells were fixed using in 4\% PFA and chemically skinned using $0.1 \%$ Triton X-100. Permeablized cells were 
incubated sequentially with a 1 in 200 dilution of Ds-Red primary antibody (Living Colors, Takara Bio, USA) and a 1 in 1000 dilution of Alexa 568 secondary antibody (Life Technologies, CA, USA). Subsequent cell counts of red fluorescent vs. total cell number gave a viable virus particle estimate of $5 \times 10^{10} / \mathrm{ml}$ and $1.49 \times 10^{9} / \mathrm{ml}$ for RGECO and RGECO-TnT respectively.

\section{Isolation of guinea pig left ventricular cardiomyocytes}

This investigation was approved by the Animal Welfare and Ethical Review Board at the University of Oxford and conforms to the UK Animals (Scientific Procedures) Act, 1986, incorporating Directive 2010/63/EU of the European Parliament. A 400g male guinea pig (Envigo, Bicester, UK) was dispatched by cervical dislocation. Cardiomyocytes were dissociated using Langendorff perfusion of, $0.8 \mathrm{mg} / \mathrm{ml}$ collagenase type II (Worthington Biochemical Corporation, Lakewood, NJ, USA) in isolation solution containing $130 \mathrm{mM} \mathrm{NaCl}$, 23mM 4-(2-hydroxyethyl)-1-piperazineethanesulphonic acid (HEPES), 21 mM glucose, 20mM taurine, $5 \mathrm{mM}$ creatine, $5 \mathrm{mM} \mathrm{MgCl} 2,5 \mathrm{mM}$ Na pyruvate, $4.5 \mathrm{mM} \mathrm{KCl}, 1 \mathrm{mM} \mathrm{NaH} \mathrm{PO}_{3}, \mathrm{pH} 7.3$ with $\mathrm{NaOH}$ ). Cells were resuspended and plated at $\sim 1 \times 10^{5}$ per $\mathrm{ml}$ in ACCITT3 cardiomyocyte culture medium as first described by Ellingsen et al ${ }^{38}$ containing $500 \mathrm{ml}$ M199 media 100 units of penicillin, $0.1 \mathrm{mg} / \mathrm{ml}$ streptomycin, $20 \mathrm{mM}$ taurine, $5 \mathrm{mM}$ creatine, $5 \mathrm{mM}$ Na pyruvate, 2mg/ml BSA, 2mM L-carnitine, 0.1pM insulin. Recombinant adenovirus was immediately added to $0.75 \mathrm{ml}$ of cell suspension to an estimated multiplicity of infection (MOI) of between 500 and 800 , infected cells were placed at $37^{\circ} \mathrm{C}$ in a $5 \% \mathrm{CO}_{2}$ atmosphere for 48 hours. This was sufficient to infect $100 \%$ of all viable rod shaped cardiomyocytes with either RGECO or RGECO-TnT.

\section{Stem cell derived cardiomyocytes}

Human iPS derived cardiomyocytes and maintenance media were purchased from Axol Bioscience, (Cambridge, UK), and handled according to manufacturer's recommendations at $37^{\circ} \mathrm{C}, 5 \% \mathrm{CO} 2$ in a humidified incubator. After 72 hours in culture they were singularised and 
re-plated onto Fibronectin $(0.5 \%) /$ Gelatin $(0.1 \%)$ coated $35 \mathrm{~mm}$ glass bottom dish (No. 0) MatTek plates (Ashland, MA, US) at 1:6.

\section{Protein purification}

$\mathrm{N}$ and $\mathrm{C}$ terminal eGFP conjugates of human recombinant $\mathrm{TnT}$ and $\mathrm{TnC}$ were produced by molecular cloning in PMW172 vector using flanking 3' NdeI and 5' EcoRI restriction sites and an internal HindIII restriction site used as a linker in each case (NEB, New England). RGECO and RGECO-TnT were also sub-cloned in to PMW172 using the same strategy. Proteins were expressed in BL21-DE3-pLysS E.coli induced using 0.4mM Isopropyl $\beta$-D-1thiogalactopyranoside for 4 hours. Bacterial pellets were recovered by centrifugation $(10,000$ $\mathrm{x} g$ for $10 \mathrm{mins}$ ) and lysed in a buffer containing $25 \mathrm{mM}$ Tris $\mathrm{HCl}, \mathrm{pH} 7.5,20 \%$ sucrose, $1 \mathrm{mM}$ EDTA, 200mM NaCl, 5M urea, 0.1\% Triton X-100. All proteins were purified using an AKTA-UPC900 FPLC using HiTrap FF chromatography columns (GE Healthcare, Amersham). GFP-TnT and TnT-GFP were purified using sequential cation (in buffer containing 6M urea, 1mM EDTA, 1mM 2-mercaptoethanol, 20mM MOPS, pH 6.0) followed by anion (in buffer containing 6M urea, 1mM EDTA, 1mM 2-mercaptoethanol 50mM Tris $\mathrm{HCl}$ pH8.0) exchange chromatography. GFP-TnC and TnC-GFP were purified by anion (pH8.5) exchange chromatography. TnI-GFP was purified by sequential cation and anion exchange chromatography. RGECO and RGECO-TnT were purified using sequential anion (pH8.0) exchange chromatography, Ammonium Sulphate fractionation (to 50\% for RGECO and 35\% for RGECO-TnT) and finally Hydrophobic Interaction Chromatography (HIC) (in buffer containing $30 \%$ ammonium sulphate, $200 \mathrm{mM} \mathrm{NaCl}_{2} 1 \mathrm{mM}$ ditiothretol and $30 \mathrm{mM}$ 4-(2hydroxyethyl)-1-piperazineethanesulphonic acid (HEPES)). Ion exchange columns were eluted using a gradient of $0-2 \mathrm{M} \mathrm{NaCl}$, the $\mathrm{HIC}$ column was eluted with a gradient of $30-0 \%$ ammonium sulphate. All eluted protein fractions were assessed for purity using $12 \%$ SDS PAGE gels, stained with coomassie brilliant blue. Wild type human recombinant TnT, TnI, 
TnC and Ala-Ser- $\alpha-\mathrm{TM}^{39}$ were purified as previously described ${ }^{40}$. Troponin complex containing either WT, GFP-TnT, GFP-TnT, GFP-TnC, TnC-GFP or RGECO-TnT were reconstituted by dialysis into buffer containing $10 \mathrm{mM}$ imidazole $\mathrm{pH} 7.0,1 \mathrm{mM}$ DTT, $0.01 \%$ azide, $0.1 \mathrm{mM} \mathrm{CaCl} 2,6 \mathrm{M}$ urea and $1 \mathrm{M} \mathrm{KCl}$, firstly urea was reduced stepwise from to 2 then $0 \mathrm{M}$ then $\mathrm{KCl}$ was reduced stepwise from $1 \mathrm{M}$ to $800-600-400-200 \mathrm{mM} \mathrm{KCl}$ in a series of 3 hour dialyses. Tn Complex was purified using size exclusion chromatography in 200mM KCl dialysis buffer (Supplementary Figure 5a), purity was analysed by SDS PAGE (Supplementary Figure 5b), and finally, purified troponin complexes are dialysed into buffer containing 5mM 1,4-Piperazinediethanesulphate $\mathrm{pH} 7.0,3,87 \mathrm{mM} \mathrm{MgCl}_{2}, 1 \mathrm{mM}$ DTT for ATPase assay experiments. Actin and myosin-S1 was extracted from rabbit skeletal muscle as previously described ${ }^{41,42}$.

\section{Actin Co-sedimentation assays}

Reconstituted Tn complex proteins $(0.5 \mu \mathrm{M})$ were co-sedimented with human Ala-Ser$\alpha-\mathrm{TM}(0.5 \mu \mathrm{M})$ and rabbit skeletal actin $(3.5 \mu \mathrm{M})$ at $384000 \mathrm{x} g$ for 15 mins by ultracentrifugation (Beckman Coulter Inc, High Wycombe). Total, supernatant and pellet fractions were visualized using coomassie blue stained 12\% SDS PAGE gels in order to ensure complete reconstitution of thin filaments prior to all ATPase assay measurements. (Supplementary Figure 5c)

\section{In vitro acto-myosin activated myosin ATPase assays}

ATPase assays were undertaken using our standard assay conditions ${ }^{6,40}$ using $3.5 \mu \mathrm{M}$ actin, $0.5 \mu \mathrm{M}$ myosin $\mathrm{S} 1,0.5 \mu \mathrm{M}$ Ala-Ser- $\alpha-\mathrm{TM}$ and $0.5 \mu \mathrm{M}$ Tn complex in buffer containing 5mM 1,4-Piperazinediethanesulphate $\mathrm{pH} 7.0,3.87 \mathrm{mM} \mathrm{MgCl}_{2}, 1 \mathrm{mM}$ DTT. In order to ensure precise thin filament protein stoichiometry, each stock was centrifuged at $384000 \mathrm{x} g$ for 15 mins. Supernatants were discarded, actin pellets were recovered in buffer containing $5 \mathrm{mM} 1,4-$ Piperazinediethanesulphate $\mathrm{pH} 7.0,3.87 \mathrm{mM} \mathrm{MgCl}_{2}, 1 \mathrm{mM}$ DTT to an equal volume of the 
discarded supernatant. Reaction mixtures were aliquoted and set to a range of free $\left[\mathrm{Ca}^{++}\right]$between 3.16nM (pCa8.5) and 31.6 $\mu \mathrm{M}(\mathrm{pCa} 4.5)$ using 1mM EGTA and the appropriate corresponding concentration of $\mathrm{CaCl}_{2}$, calculated using Maxchelatior software (http://maxchelator.stanford.edu/CaEGTA-TS.htm). Calcium-sensitivity data was fitted to the Hill equation using Kaleidagraph (Synergy Software, Inc (USA)).

Hill equation: $A=\frac{A_{\min }+\left(A_{\max }-A_{\min }\right)}{1+10^{\left(\left(p C a-p C a_{50}\right) \times n_{H}\right)}}$

Where: $\mathrm{A}=$ ATPase rate; $\mathrm{A}_{\min }=$ Minimum ATPase rate; $\mathrm{A}_{\max }=$ Maximum ATPase rate; $\mathrm{pCa}=-\log \left[\mathrm{Ca}^{++}\right] ; \mathrm{pCa} 50=-\log \left[\mathrm{Ca}^{++}\right]$required for half maximum ATPase activity; $n_{\mathrm{H}}=$ Hill coefficient.

\section{Calcium binding, $K_{d}$ and kinetic calculations}

To measure steady state $\mathrm{Ca}^{++}$binding affinity $\left(K_{\mathrm{d}}\right)$ for RGECO and RGECO-TnT, $3 \mu \mathrm{M}$ of protein was dialysed into buffer containing 130mM NaCl, 10mM 4-(2-hydroxyethyl)-1piperazineethanesulphonic acid (HEPES), 1mM dithiothretol, $\mathrm{pH} 7.3$ and either $0,1.3$ or 3.9mM $\mathrm{MgCl}_{2}$. A range of free $\left[\mathrm{Ca}^{++}\right]$conditions were set between $3.16 \mathrm{nM}(\mathrm{pCa} 8.5)$ and 31.6 $\mu \mathrm{M}(\mathrm{pCa} 4.5)$ using $1 \mathrm{mM}$ EGTA and the appropriate corresponding concentration of $\mathrm{CaCl}_{2}$. Steady state fluorescence readings were made in an Ultraclear bottom 96 well microplate using a FLUOstar Omega plate reader (BMG LABTEC, Ortenberg, Germany), using a 544nm excitation filter and 590/10nm emission filter at both 25 and $37^{\circ} \mathrm{C}$. Resultant fluorescence emission intensities were plotted vs free $\left[\mathrm{Ca}^{++}\right]$and fitted to the Hill equation to calculate $K_{\mathrm{d}}$ values for each protein and condition.

To measure $\mathrm{Ca}^{++}$displacement $\left(k_{\text {off }}\right), 125 \mathrm{nM}$ RGECO or RGECO-TnT plus $5 \mu \mathrm{M}$ $\mathrm{CaCl}_{2}$ was mixed with $5 \mathrm{mM}$ EGTA in a buffer containing $130 \mathrm{mM} \mathrm{NaCl}, 10 \mathrm{mM} 4-(2-$ hydroxyethyl)-1-piperazineethanesulphonic acid (HEPES) $1.3 \mathrm{mM} \mathrm{MgCl}_{2}, 1 \mathrm{mM}$ dithiothretol, 
pH7.3 with NaOH. RGECO or RGECO-TnT was loaded into a Stopped-flow system (HiTech Scientific, Bradford-on-Avon, UK), concentrations after mixing 1:1 in the stopped-flow. Fluorescence was excited at 546nm (100W Xe/Hg lamp and monochromator) and emission monitored through a OG-590 glass filter. The resultant data was fitted to a single exponential decrease in fluorescence of 50-100\%, depending upon temperature. To measure calcium binding $\left(k_{\mathrm{on}}\right), 125 \mathrm{nM}$ RGECO or RGECO-TnT was measured at $10 \mu \mathrm{M}$ free calcium by mixing with a buffer containing $2.125 \mathrm{mM}$ Ca.EGTA and $0.2 \mathrm{mM}$ EGTA. The stopped-flow fluorescence filter set up was idetical to that of the displacement measurements. A large increase in fluorescence upon addtion of calcium was fitted to a single exponetial. The observed single exponential rate constant, $k_{\mathrm{obs}}$, was extracted for $k_{\mathrm{on}}$ and $k_{\mathrm{off}}$ for both sensors, at a range of temperatures between 25 and $37^{\circ} \mathrm{C}$. To estimate the dissociation constant we using the

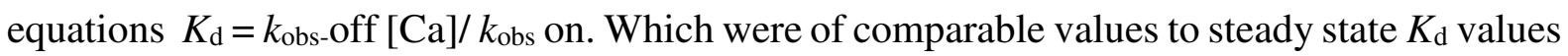
obtained previously.

\section{Determination of Quantum Yield and Molar Extinction Co-efficient}

Quantum yield and molar extinction co-efficient was determined for each Ca++ sensor using a method adapted from Zhao et $a l^{25}$. Briefly, standards for quantum yield determination were mCherry (for RGECO) and RGECO for RGECO-TnT. Briefly, the concentration of protein in buffer containing 10mM 4-(2-hydroxyethyl)-1-piperazineethanesulphonic acid (HEPES), $1.3 \mathrm{mM} \mathrm{MgCl}_{2}$ and $1 \mathrm{mM}$ dithiothreitol was determined using BCA assay (Pierce) and set to either $\mathrm{pCa} 4.5$ of 8.5 , the concentration of each protein was reduced to an absorbance at the excitation wavelength between 0.2 and 0.6 . A series of dilutions to absorbance's of 0.01 , 0.02, 0.03 and 0.04 were made for each protein solution and standard. The fluorescence emission spectra at Ex $\mathrm{F}_{568}$ of each dilution of each standard and protein solution were recorded using an RF-1501 spectrofluorimeter (Shimadzu, Kyoto, Japan). The total fluorescence intensities were then obtained by integration. Integrated fluorescence intensity vs. absorbance 
was plotted for each protein and each standard. Quantum yields were determined from the slopes $(\mathrm{S})$ of each line using the equation: $\Phi$ protein $=\Phi$ standard $\times($ Sprotein/Sstandard $)$.

Extinction coefficients were determined by first measuring the absorption spectrum of both RGECO and RGECO-TnT at pCa8.5 and 4.5 in the buffer above using a plate reader (BMG LABTECH, Offenburg, Germany). Peak Absorbance wavelengths were determined to be $\mathrm{A}_{465}$ in low $\mathrm{Ca}^{++}$and $\mathrm{A}_{581}$ in high $\mathrm{Ca}^{++}$. Absorbance measurements were automatically converted to $1 \mathrm{~cm}$ path length using BMG Omega software. Extinction coefficients of each protein were calculated by dividing the peak absorbance maximum by the previously determined concentration of protein.

\section{Subcellular fractionation and western blotting}

Adult guinea pig left ventricular cardiomyocytes were fractionated to recover cytoplasmic and sarcomeric/cytoskeletal samples in a method adapted from Simon et $a l^{43}$. Briefly, 300,000 cardiomyocytes were pelleted by centrifugation, resuspended in buffer containing, 20mM Tris $\mathrm{HCl} \mathrm{pH7.4,2mM} \mathrm{EDTA,} \mathrm{0.5mM} \mathrm{EGTA,} \mathrm{0.3mM} \mathrm{sucrose.} \mathrm{Cells} \mathrm{were}$ homogenised in a glass homogeniser for 1 minute. Cells were pelleted at 1000xg for 5mins, the supernatant / cytoplasmic fraction was retained for SDS PAGE analysis and western blotting. The cell pellet was washed 3 times in fractionation buffer $+1 \%$ Triton X-100 each time pelleting the sarcomeric fraction by centrifugation at $1000 \mathrm{xg}$ for $5 \mathrm{mins}$. Finally, the sarcomeric fraction was resuspended in fractionation buffer (without Triton X-100) and prepared for SDS PAGE analysis and western blotting. Cytoplasmic and Sarcomeric fractions were western blotted using anti-cTnT (1 in 2000) (Sigma, Poole, UK) and anti-ERK (1 in 4000) (Cell Signaling Technologies, Massachusetts, USA) primary antibodies and rabbit HRP (1 in 8-16000) secondary antibodies using PVDF membranes and visualised and analysed using GelDoc Image Lab software (Bio-Rad Laboratories, California, USA) . 


\section{Measurement of sarcomere shortening and fura2 $\mathrm{Ca}^{++}$transients}

Sarcomere shortening and $\mathrm{Ca}^{++}$transient measurements were performed using IonOptix $\mu$ step apparatus and the manufacturers' standard operating instructions. Briefly: cultured cardiomyocytes were loaded with fura $2 \mathrm{Ca}^{++}$indicator by incubation with either $0.1,0.5,1.0$ or $5.0 \mu \mathrm{M}$ fura2-AM ester (Life Technologies) in the presence of $2 \mu \mathrm{M}$ F127 pluronic in 'perfusion buffer' (150mM NaCl, 10mM 4-(2-hydroxyethyl)-1-piperazineethanesulphonic acid (HEPES), $7 \mathrm{mM}$ glucose, $1 \mathrm{mM} \mathrm{MgCl}, 1 \mathrm{mM} \mathrm{KCl}, 0.3 \mathrm{mM} \mathrm{NaH}_{2} \mathrm{PO}_{3}, \mathrm{pH} 7.4$ with $\mathrm{NaOH}$ ) containing $250 \mu \mathrm{M} \mathrm{CaCl} 2$ for 5 mins, followed by a 10 minute wash in perfusion buffer containing $500 \mu \mathrm{M} \mathrm{CaCl}_{2}$ to remove any excess label. For experiments using SBFI 0.1, 0.5, 1.0 or $5.0 \mu \mathrm{M}$ were loaded in the same manner. Experiments using FluoVolt (ThermoFisher) a 1/1000 dilution was used according the manufacturer's instructions. The loaded cells were then allowed to settle to the bottom of a perfusion chamber with a 1.5 thickness cover slip base, which was mounted on an inverted fluorescence microscope. Cells were perfused with Perfusion buffer containing $1.8 \mathrm{mM} \mathrm{CaCl}_{2}$, and electrically paced at 40 volts. Pacing frequency was set at $0.5 \mathrm{~Hz}$ in order to accurately measure resting diastolic $\left[\mathrm{Ca}^{++}\right]_{\mathrm{i}}$. Sarcomere shortening was captured by Fourier transform of the cardiomyocyte striations under phase contrast microscopy using a switching rate of $100 \mathrm{~Hz}$. fura2 $\mathrm{Ca}^{++}$transients were captured simultaneously, using the ratio of fura2 fluorescence emission at $365 / 380 \mathrm{~nm}$ at a switching rate of $1000 \mathrm{~Hz}$. All contracting cardiomyocytes were measured for contractility and fura2 $\mathrm{Ca}^{++}$, any cells displaying asynchronous contractility, excessive blebbing/dysmorphology were ignored for acquisition, whilst any cell with contractile magnitudes or velocities exceeding 2 standard deviations from the mean upon analysis were also excluded as product of phenotypic heterogeneity of primary cells in culture losing function and morphology over time. To compare sarcomere shortening and fura $2 \mathrm{Ca}^{++}$transients in the presence of contractility or $\mathrm{Ca}^{++}$ modifying small molecules MYK-461 $(0.25 \mu \mathrm{M})$, Levosimendan $(10 \mu \mathrm{M})$ and Flecainide 
$(0.5 \mu \mathrm{M}), 200 \mu \mathrm{l}$ of cultured (48 Hours) cardiomyocytes were incubated in either drug or DMSO vehicle for 5mins. The entire cell preparation was pipetted onto the microscope perfusion chamber buffer containing the either drug or vehicle was perfused at $0.75 \mathrm{ml} / \mathrm{min}$ for the duration of the experiment. All contracting cells were measured (except those not meeting the exclusion criteria above), no preparation of cells was left for more than $15 \mathrm{mins}$ before being replaced for a fresh batch of pre-incubated cells. At least 3 cell preparations were analyzed for each DMSO/drug comparison. No differences or clustering was observed between each cell preparation assessed.

\section{RGECO imaging in fixed cells}

Adult ventricular cardiomyocytes were exposed to recombinant adenovirus immediately after isolation in $0.75 \mathrm{ml}$ of cell suspension to an estimated multiplicity of infection (MOI) of between 500 and 800 , infected cells were placed at $37^{\circ} \mathrm{C}$ in a $5 \% \mathrm{CO}_{2}$ atmosphere for 48 hours. At 48 hours an aliquot was taken and paraformaldehyde to a final concentration of $4 \%$ was added, at $10 \mathrm{mins}$ cells were pelleted $(600 \mathrm{rpm}, 2 \mathrm{mins})$ in a benchtop centrifuge, washed with 1xPBS and resuspended in PBS. Cells were spun (Cytospin, Thermo Scientific) onto glass slides, and ringed with a PAP pen (Sigma). Human iPS-derived cardiomyocytes were plated as above and incubated to day 7 following thaw before washing with 1xPBS and fixation with $4 \%$ paraformaldehyde. For infection, virus was diluted 1:10 from the stock solution and used at $1 \mu \mathrm{l} /$ dish 24 hours after replating. Permeabilisation with $0.1 \%$ Triton X100 in Tris Buffered Saline for 10mins at room temperature was followed by blocking $(0.2 \%$ albumin in permeabilisation buffer) for 20mins. Primary antibodies (Mouse monoclonal antialpha actinin (Sigma, clone EA-53) rabbit polyclonal anti-DsRed (Clontech) were diluted 1:2000, and 1:200 in blocking buffer respectively. Three hours after primary incubation cells were washed in permeabilisation buffer, and counter stained with Alexa-488 anti-mouse, and Alexa-568 anti-rabbit fab fragment secondary antibodies (Invitrogen), nuclear counterstaining 
was with TO-PRO-3 (Invitrogen), for an hour before washing and mounting (Vectashield, Vector labs). Images were acquired on a Leica SP5 confocal microscope with a 63x oil immersion lens, and intensity plots prepared with the plot profile function in ImageJ.

\section{Live cell Imaging Microscope}

An inverted IX81 frame (Olympus, Japan), with a custom 7 LED array (Cairn Research, Faversham, UK), automated stage (Prior Scientific, Cambridge, UK), lens turret, and filter wheel is housed in a custom heated, humidified chamber (Solent Scientific, Segensworth, UK) with image collection on two C-1900 EMCCD cameras (Hamamatsu, Japan) mounted on a DC2 beam splitter (Photometrics, UK). For isolated RGECO imaging, single camera mode image acquisition through an Olympus LUCPlanFLN 40x objective lens (NA 0.60), or an Olympus UPlanFLN 10x lens (NA 0.3), using CellR software (Olympus) was used with uninterrupted recording of the calcium transient via a $5 \mathrm{msec} 568 \mathrm{~nm}$ LED illumination pulse and the RFP filter set (DS/FF01-560/25-25, T565lpxr dichroic mirror, and ET620/60 emission filter, all Semrock). Simultaneous calcium transients from GGECO and RGECO indicators was acquired through an Olympus PlanApo 60x oil objective lens (NA 1.42), through a quadband filter set (band pass filter (DS/FF01-387/485/559/649-25), dichroic quad-edge beam splitter (DS/FF410/504/582/669-Di01-25x36), and quad-band emission filter (DS/FF01440/521/607/700-25) all Semrock with fluorescent emissions recorded through a Dual-View system (DC2, Photometrics) with green (520/30nm) and red (630/50nm) channels to separate cameras controlled through CellR (Olympus, Japan). RGECO and RGECO-TnT adenovirally induced vGPCMs were treated with $250 \mathrm{nM}$ MYK-461, $10 \mu \mathrm{M}$ Levosimendan, or $0.5 \mu \mathrm{M}$ Flecainide for $20 \mathrm{mins}$ then video rate movies with $0.5 \mathrm{~Hz}$ pacing were acquired for $28 \mathrm{secs}$ using the UPlanFLN 10x lens.

\section{Transient analysis software \& statistics}


Raw image data was extracted using CellR (Olympus), and analysed in Excel (Microsoft). From a single cell 10 intensity transients over time were extracted and averaged to give a single transient in a 2 second interval per cell; 3 transients were averaged for iPSCMs. Time to $50 \%$ contraction, or time to $50 \%$ baseline (from peak) was determined from these traces.

Comparative peak intensity analysis was performed using paired control vs drug exposed datasets obtained from the same cell preparation. In brief the $\Delta \mathrm{F} / \mathrm{F}$ measurement described for intensiometric indicators ${ }^{34}$ was used.

$$
\frac{\Delta F}{F}=\frac{F(t)-F(\min )}{F(\min )}
$$

Where $F(t)$ is the fluorescence intensity at time (t), and $\mathrm{F}(\mathrm{min})$ the minimum fluorescence intensity during the 2 second averaged dataset taken to be representative of a single cell.

Comparisons presented in Figure $2 \mathrm{~b}$ were obtained by dividing or subtracting the relevant value of the paired control population from that of the drug exposed population based on the data in Supplementary tables $3,4 \& 5$.

Where relative intensity data is presented, the following calculation was used

$$
I=\frac{F(t)-F(\min )}{F(\max )-F(\min )}
$$

Where $I$, intensity, is a ratio of the fluorescence signal $(F(t))$ scaled according to the maximum $(F(\max ))$, and minimum $(F(\min ))$ response of the cell during the observation.

Unfiltered transient graphs were plotted using KaleidaGraph (Synergy Software), and dot plots with GraphPad Prism (GraphPad software). Groups were compared using unpaired Students t-test (MYK-461, Levosimendan, Flecainide) or one-way ANOVA with post-hoc 
bioRxiv preprint doi: https://doi.org/10.1101/268003; this version posted April 16, 2018. The copyright holder for this preprint (which was not certified by peer review) is the author/funder, who has granted bioRxiv a license to display the preprint in perpetuity. It is made available under aCC-BY-NC-ND 4.0 International license.

Dunn's test (pacing frequency comparisons). Simultaneous RGECO and GGECO calcium traces from a single cell, and average responses at different pacing frequencies were normalized for presentation.

\section{iPS-derived cardiomyocyte movement analysis}

Cells plated and prepared as above were imaged in bright field mode at video rate over a 2 minute interval using the LUCPlanFLN 40x lens. Quantification of cell activity was scored for actively/non-actively contracting cells. An activity contracting cell was regarded as a cell presenting at least a single contraction within the 2 minute interval. The spontaneous beat frequency for these cells is $0.52 \mathrm{~Hz}+/-0.15 \mathrm{~Hz}$, with $>90 \%$ cardiomyocyte purity based on $\mathrm{TnI}$ positivity $^{26}$.

\section{Impedance assessment of contractility}

iCell cardiomyocytes (CDI) were seeded at 20,000 cells/well into RTCA plates and loaded onto an xCELLigence RTCA Cardio system (ACEA bioscience) housed in a humidified incubator at $37^{\circ} \mathrm{C}$ with a $5 \% \mathrm{CO}_{2}$ atmosphere, this was interrupted for feeding on alternate days. Contractility was monitored via impedance assessment at $12.9 \mathrm{msec}$ intervals. At day 14 post seeding, with robust signals apparent in all wells, cells were loaded with FLIPR 5 (Molecular Devices) around the recommended 1x final working concentration. The recommended loading phase for FLIPR Calcium 5 is $1 \mathrm{hr}$, recording continued for $24 \mathrm{hrs}$. Raw transient data for the windows indicated together with transient amplitude and beat rate over the first two hours of the experiment were extracted using the RTCA software and prepared for presentation using Microsoft Excel. 
bioRxiv preprint doi: https://doi.org/10.1101/268003; this version posted April 16, 2018. The copyright holder for this preprint (which was not certified by peer review) is the author/funder, who has granted bioRxiv a license to display the preprint in perpetuity. It is made available under aCC-BY-NC-ND 4.0 International license.

\section{Predictive structural modelling}

The predicted models for the RGECO-TnT fusion were generated using Raptor $\mathrm{X}^{44}$ and Swiss-PDB Viewer ${ }^{45}$ using the primary amino acid sequence provided in Supplementary

\section{figure 12.}

\section{References:}

Heilbrunn, L. V. \& Wiercinski, F. J. The action of various cations on muscle protoplasm. J Cell Comp Physiol 29, 15-32 (1947).

Ebashi, S., Endo, M. \& Otsuki, I. Control of muscle contraction. Q Rev Biophys 2, 351-384 (1969). Pirani, A. et al. An atomic model of the thin filament in the relaxed and Ca2+-activated states. J Mol Biol 357, 707-717 (2006).

Gordon, A. M., Homsher, E. \& Regnier, M. Regulation of contraction in striated muscle. Physiol Rev 80, 853-924 (2000).

Eisner, D. A., Caldwell, J. L., Kistamas, K. \& Trafford, A. W. Calcium and Excitation-Contraction Coupling in the Heart. Circ Res 121, 181-195, doi:10.1161/CIRCRESAHA.117.310230 (2017).

Robinson, P., Griffiths, P. J., Watkins, H. \& Redwood, C. S. Dilated and hypertrophic cardiomyopathy mutations in troponin and alpha-tropomyosin have opposing effects on the calcium affinity of cardiac thin filaments. Circ Res 101, 1266-1273 (2007).

Spudich, J. A. Hypertrophic and dilated cardiomyopathy: four decades of basic research on muscle lead to potential therapeutic approaches to these devastating genetic diseases. Biophys J 106, 1236-1249, doi:10.1016/j.bpj.2014.02.011 (2014).

Ponikowski, P. et al. Heart failure: preventing disease and death worldwide. ESC Heart Fail 1, 4-25, doi:10.1002/ehf2.12005 (2014).

Pollesello, P., Papp, Z. \& Papp, J. G. Calcium sensitizers: What have we learned over the last 25 years? Int J Cardiol 203, 543-548, doi:10.1016/j.ijcard.2015.10.240 (2016).

Grynkiewicz, G., Poenie, M. \& Tsien, R. Y. A new generation of $\mathrm{Ca2+}$ indicators with greatly improved fluorescence properties. J Biol Chem 260, 3440-3450 (1985).

Smith, N. A. et al. Fluorescent $\mathrm{Ca}(2+)$ indicators directly inhibit the Na,K-ATPase and disrupt cellular functions. Sci Signal 11, doi:10.1126/scisignal.aal2039 (2018).

2 Backx, P. H. \& Ter Keurs, H. E. Fluorescent properties of rat cardiac trabeculae microinjected with fura-2 salt. Am J Physiol 264, H1098-1110, doi:10.1152/ajpheart.1993.264.4.H1098 (1993).

Kaestner, L. et al. Genetically encoded Ca2+ indicators in cardiac myocytes. Circ Res 114, 16231639, doi:10.1161/CIRCRESAHA.114.303475 (2014).

14 Lin, M. Z. \& Schnitzer, M. J. Genetically encoded indicators of neuronal activity. Nat Neurosci 19, 1142-1153, doi:10.1038/nn.4359 (2016).

5 Tian, L., Hires, S. A. \& Looger, L. L. Imaging neuronal activity with genetically encoded calcium indicators. Cold Spring Harb Protoc 2012, 647-656, doi:10.1101/pdb.top069609 (2012).

16 Akerboom, J. et al. Genetically encoded calcium indicators for multi-color neural activity imaging and combination with optogenetics. Front Mol Neurosci 6, 2, doi:10.3389/fnmol.2013.00002 (2013).

17 Paul, D. M., Morris, E. P., Kensler, R. W. \& Squire, J. M. Structure and orientation of troponin in the thin filament. J Biol Chem 284, 15007-15015, doi:10.1074/jbc.M808615200 (2009).

8 Williams, D. A., Fogarty, K. E., Tsien, R. Y. \& Fay, F. S. Calcium gradients in single smooth muscle cells revealed by the digital imaging microscope using Fura-2. Nature 318, 558-561 (1985). 
bioRxiv preprint doi: https://doi.org/10.1101/268003; this version posted April 16, 2018. The copyright holder for this preprint (which was not certified by peer review) is the author/funder, who has granted bioRxiv a license to display the preprint in perpetuity. It is made available under aCC-BY-NC-ND 4.0 International license.

19 Poenie, M., Alderton, J., Tsien, R. Y. \& Steinhardt, R. A. Changes of free calcium levels with stages of the cell division cycle. Nature 315, 147-149 (1985).

20 Miller, E. W. et al. Optically monitoring voltage in neurons by photo-induced electron transfer through molecular wires. Proc Natl Acad Sci U S A 109, 2114-2119, doi:10.1073/pnas.1120694109 (2012).

21 Minta, A. \& Tsien, R. Y. Fluorescent indicators for cytosolic sodium. J Biol Chem 264, 1944919457 (1989).

22 Kamgoue, A., Ohayon, J., Usson, Y., Riou, L. \& Tracqui, P. Quantification of cardiomyocyte contraction based on image correlation analysis. Cytometry A 75, 298-308, doi:10.1002/cyto.a.20700 (2009).

23 Jonsson, M. K., Wang, Q. D. \& Becker, B. Impedance-based detection of beating rhythm and proarrhythmic effects of compounds on stem cell-derived cardiomyocytes. Assay Drug Dev Technol 9, 589-599, doi:10.1089/adt.2011.0396 (2011).

24 Rodriguez, E. A. et al. The Growing and Glowing Toolbox of Fluorescent and Photoactive Proteins. Trends Biochem Sci 42, 111-129, doi:10.1016/j.tibs.2016.09.010 (2017).

25 Zhao, Y. et al. An expanded palette of genetically encoded $\mathrm{Ca}(2)(+)$ indicators. Science 333, 1888-1891, doi:10.1126/science.1208592 (2011).

26 Chang, Y. F. et al. Non-invasive phenotyping and drug testing in single cardiomyocytes or betacells by calcium imaging and optogenetics. PLoS One 12, e0174181, doi:10.1371/journal.pone.0174181 (2017).

27 Fabiato, A. \& Fabiato, F. Effects of $\mathrm{pH}$ on the myofilaments and the sarcoplasmic reticulum of skinned cells from cardiace and skeletal muscles. The Journal of physiology 276, 233-255 (1978).

28 Griffiths, E. J. Calcium handling and cell contraction in rat cardiomyocytes depleted of intracellular magnesium. Cardiovasc Res 47, 116-123 (2000).

29 Shinnawi, R. et al. Monitoring Human-Induced Pluripotent Stem Cell-Derived Cardiomyocytes with Genetically Encoded Calcium and Voltage Fluorescent Reporters. Stem Cell Reports 5, 582-596, doi:10.1016/j.stemcr.2015.08.009 (2015).

30 Green, E. M. et al. A small-molecule inhibitor of sarcomere contractility suppresses hypertrophic cardiomyopathy in mice. Science 351, 617-621, doi:10.1126/science.aad3456 (2016).

31 Papp, Z. et al. Levosimendan: molecular mechanisms and clinical implications: consensus of experts on the mechanisms of action of levosimendan. Int J Cardiol 159, 82-87, doi:10.1016/j.ijcard.2011.07.022 (2012).

32 Benhorin, J. et al. Effects of flecainide in patients with new SCN5A mutation: mutation-specific therapy for long-QT syndrome? Circulation 101, 1698-1706 (2000).

33 Paul, A. A., Witchel, H. J. \& Hancox, J. C. Inhibition of the current of heterologously expressed HERG potassium channels by flecainide and comparison with quinidine, propafenone and lignocaine. British journal of pharmacology 136, 717-729 (2002).

34 Hilliard, F. A. et al. Flecainide inhibits arrhythmogenic Ca2+ waves by open state block of ryanodine receptor $\mathrm{Ca} 2+$ release channels and reduction of $\mathrm{Ca} 2+$ spark mass. J Mol Cell Cardiol 48, 293-301, doi:10.1016/j.yjmcc.2009.10.005 (2010).

35 Watanabe, H., Steele, D. S. \& Knollmann, B. C. Mechanism of antiarrhythmic effects of flecainide in catecholaminergic polymorphic ventricular tachycardia. Circ Res 109, 712-713, doi:10.1161/CIRCRESAHA.111.251322 (2011).

36 Surdo, N. C. et al. FRET biosensor uncovers CAMP nano-domains at beta-adrenergic targets that dictate precise tuning of cardiac contractility. Nat Commun 8, 15031, doi:10.1038/ncomms15031 (2017).

37 Luo, J. et al. A protocol for rapid generation of recombinant adenoviruses using the AdEasy system. Nature protocols 2, 1236-1247 (2007). 
bioRxiv preprint doi: https://doi.org/10.1101/268003; this version posted April 16, 2018. The copyright holder for this preprint (which was not certified by peer review) is the author/funder, who has granted bioRxiv a license to display the preprint in perpetuity. It is made available under aCC-BY-NC-ND 4.0 International license.

Ellingsen, O. et al. Adult rat ventricular myocytes cultured in defined medium: phenotype and electromechanical function. Am J Physiol 265, H747-754 (1993).

39 Monteiro, P. B., Lataro, R. C., Ferro, J. A. \& Reinach Fde, C. Functional alpha-tropomyosin produced in Escherichia coli. A dipeptide extension can substitute the amino-terminal acetyl group. J Biol Chem 269, 10461-10466 (1994).

40 Robinson, P. et al. Alterations in thin filament regulation induced by a human cardiac troponin T mutant that causes dilated cardiomyopathy are distinct from those induced by troponin $T$ mutants that cause hypertrophic cardiomyopathy. J Biol Chem 277, 40710-40716 (2002).

41 Pardee, J. D. \& Spudich, J. A. Purification of muscle actin. Methods Cell Biol 24, 271-289 (1982).

42 Weeds, A. G. \& Taylor, R. S. Separation of subfragment-1 isoenzymes from rabbit skeletal muscle myosin. Nature 257, 54-56 (1975).

43 Simon, J. N. et al. Ceramide-mediated depression in cardiomyocyte contractility through PKC activation and modulation of myofilament protein phosphorylation. Basic Res Cardiol 109, 445, doi:10.1007/s00395-014-0445-6 (2014).

44 Kallberg, M. et al. Template-based protein structure modeling using the RaptorX web server. Nature protocols 7, 1511-1522, doi:10.1038/nprot.2012.085 (2012).

45 Guex, N. \& Peitsch, M. C. SWISS-MODEL and the Swiss-PdbViewer: an environment for comparative protein modeling. Electrophoresis 18, 2714-2723, doi:10.1002/elps.1150181505 (1997).

\section{Funding:}

Work in MJD's lab is supported by the Wellcome Trust (WT098519MA), YFC was supported by a pump priming grant from the BHF Centre of Excellence award to Oxford University (RE/08/004/23915 \& RE/13/1/30181). MJD's Cross appointment in Osaka is made possible by the JSPS International Joint Research Promotion Program to Osaka University. XZ \& YAA are employees of ACEA Biosciences. PR, AS, HW and CR are supported by the British Heart Foundation (Programme grant RG/12/16/29939) and the British Heart Foundation Centre of Research Excellence (Oxford).

\section{Competing Financial Interests statement:}

None of the authors declares a financial interest.

\section{Author Contributions:}

PR and MJD conceptualized the study. PR, CR, MJD, AJS designed and interpreted the experiments. PR and AJS performed the chemical dye experiments. PR and AJS made the RGECO-troponin conjugate. AJS constructed and produced the RGECO-TnT adenovirus. PR, AJS, KS, MAG performed the characterisation of the GECO's. CNB and AJS provided the RGECO-TnT predicted molecular model. CNB, Y-FC, FAB, XZ, YAA performed the iPS-CM experiments. PR and AJS performed the adult cardiomyocyte experiments. AJS provided analytic tools. AJS and PR performed all analysis. MJD, CR, PR, AJS wrote and edited the manuscript and all authors provided comments on this manuscript. 
bioRxiv preprint doi: https://doi.org/10.1101/268003; this version posted April 16, 2018. The copyright holder for this preprint (which was not certified by peer review) is the author/funder, who has granted bioRxiv a license to display the preprint in perpetuity. It is made

a

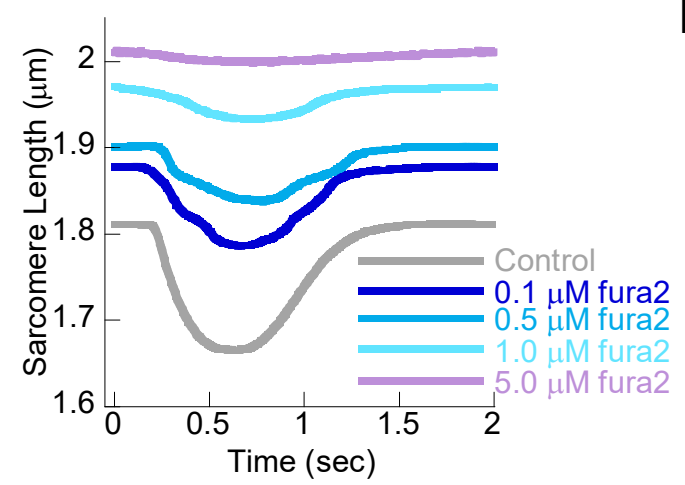

C

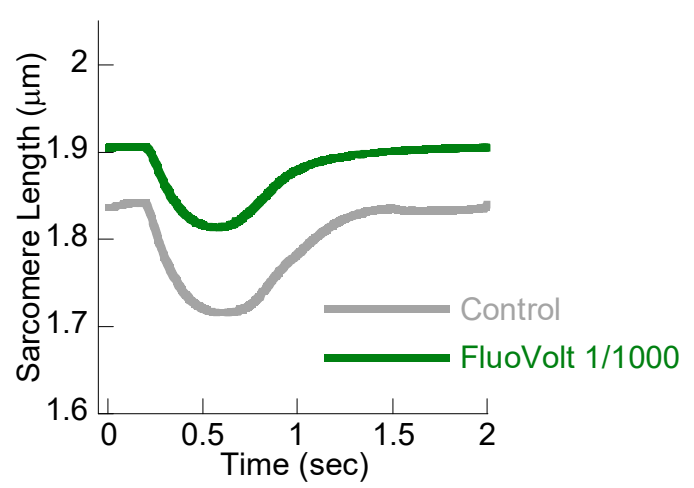

e

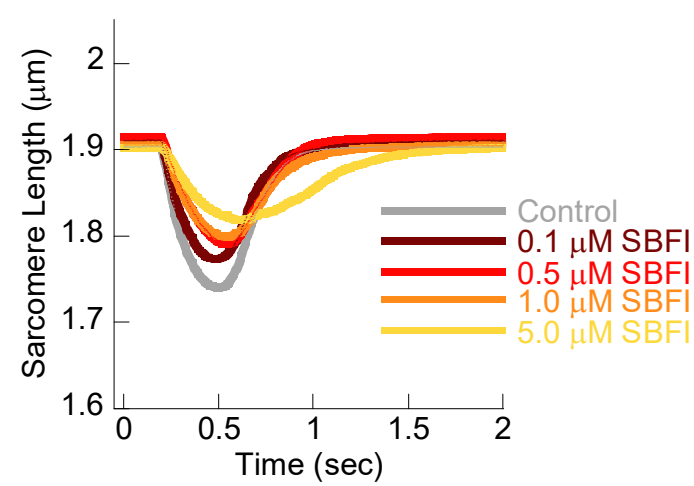

g

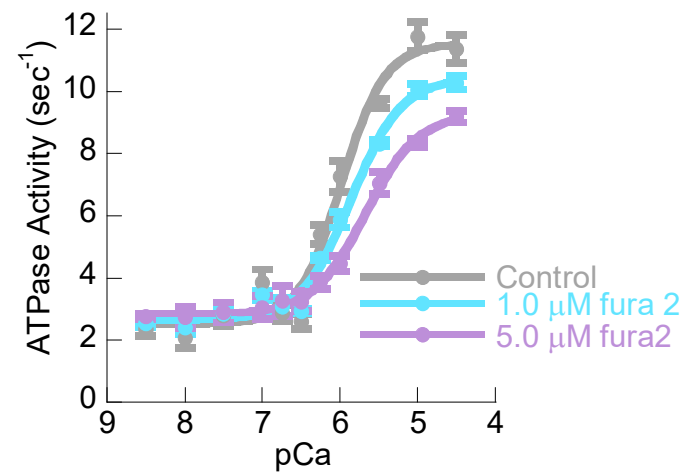

b

d

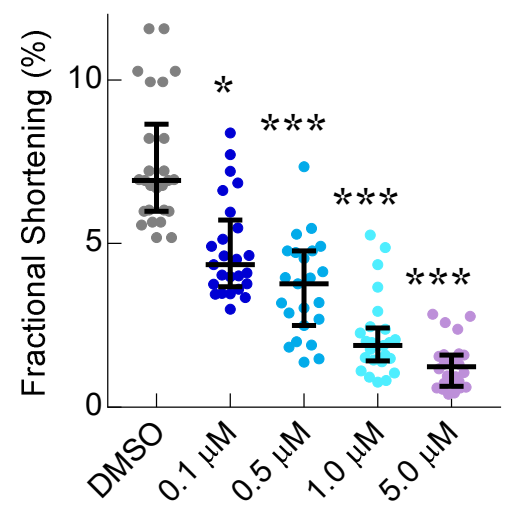

$\mathbf{f}$

$\mathbf{h}$
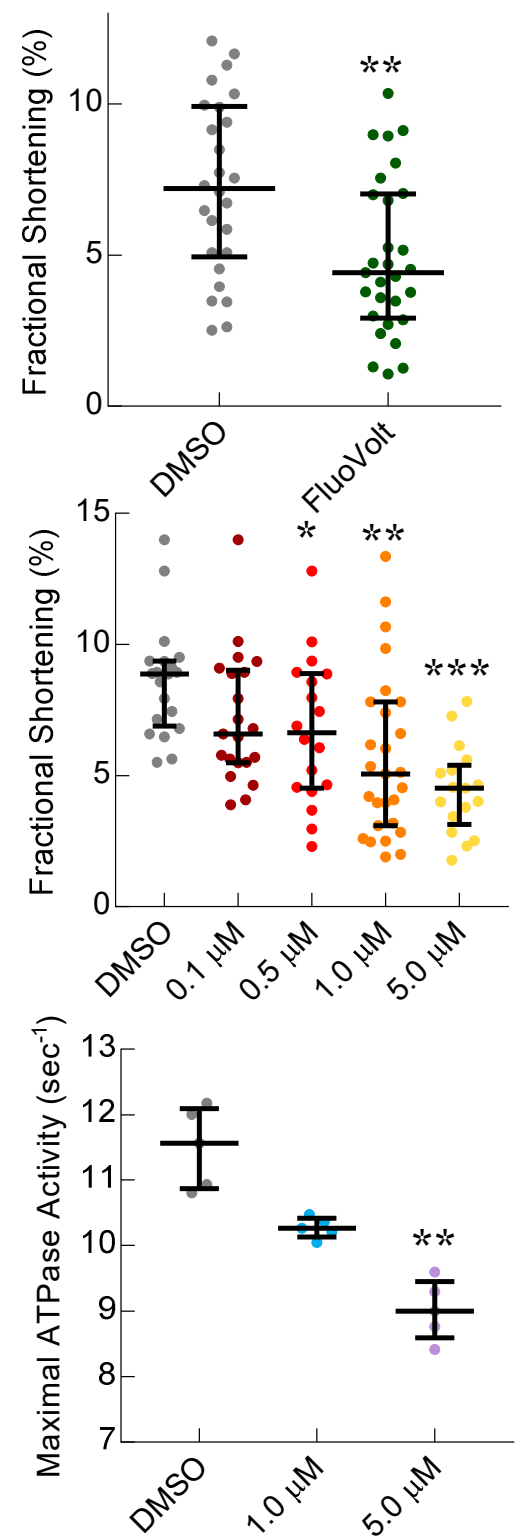

Figure 1. Chemical dyes to measure intracellular ionic flux is deleterious to cardiac contractility. Unloaded sarcomere shortening of electrically paced $(0.5 \mathrm{~Hz})$ isolated adult cardiomyocytes was used to test cardiac contractile function in (a,c,e). Control (grey) was compared to cells loaded with $0.1 \mu \mathrm{M}$ (royal blue), $0.5 \mu \mathrm{M}$ (blue), $1.0 \mu \mathrm{M}$ (teal) or $5.0 \mu \mathrm{M}$ (mauve) fura2-AM ester (a). or with 1/1000 dilution of Fluovolt-AM ester (green) loaded according to the manufacturers instructions (c) or with $0.1 \mu \mathrm{M}$ (brown), $0.5 \mu \mathrm{M}$ (red), $1.0 \mu \mathrm{M}$ (orange) or $5.0 \mu \mathrm{M}$ (yellow) SBFI-AM ester (e). Significant reduction in fractional shortening was observed in each case (b). Working concentrations of Fluovolt-AM ester reduced contractile magnitude and caused basal relaxation of cardiomyocytes (d). Exposure to increasing concentrations of the sodium dye SBFI-AM ester also reduced contractile magnitude however did not affect basal relaxation of cardiomyocytes (f). Myofilament function was assessed using in vitro actin activated acto-myosin S1 ATPase assays. Myofilaments containing wild type control Tn complexes in DMSO (grey) were compared to those in the presence of $1 \mu \mathrm{M}$ (blue) or $5 \mu \mathrm{M}$ (mauve) fura2-AM ester. Note the shift of the trace down, indicative of myosin ATPase inhibition, as well as right (g). $n=5$ error bars are \pm SEM. The presence of fura2-AM ester reduced the maximal ATPase activity even with concentrations a fraction of the levels typically found in cells (h). For all dot plots $(\mathbf{b}, \mathbf{d}, \mathbf{f}, \mathbf{h})$ lines give the median average and error bars are \pm interquartile range $*=\mathrm{p}<0.05, * *=\mathrm{p}<0.01$ and $* * *=\mathrm{p}<0.001$ using one way ANOVA) 
bioRxiv preprint doi: https://doi.org/10.1101/268003; this version posted April 16, 2018. The copyright holder for this preprint (which was not certified by peer review) is the author/funder, who has granted bioRxiv a license to display the preprint in perpetuity. It is made available under aCC-BY-NC-ND 4.0 International license.

b

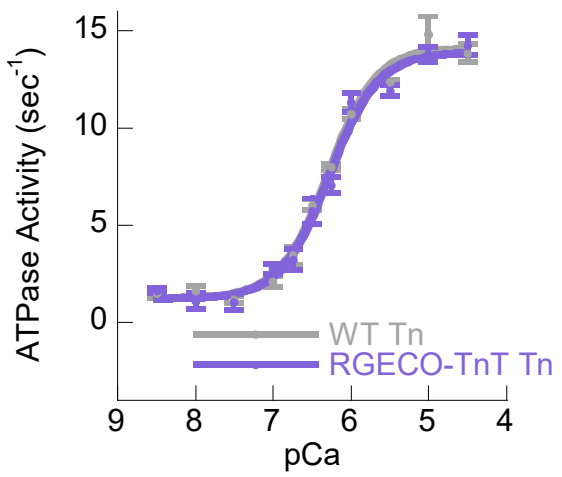

d

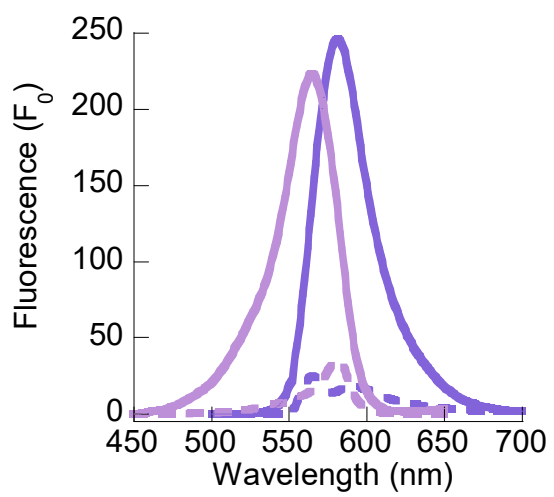

a

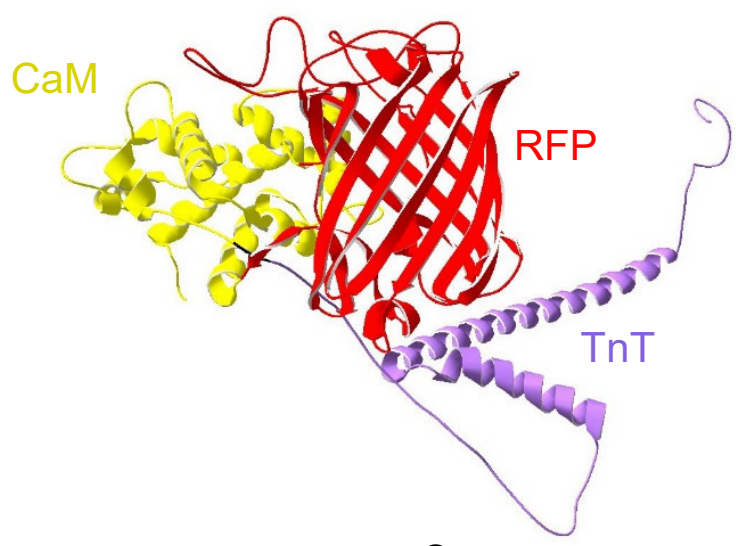

C

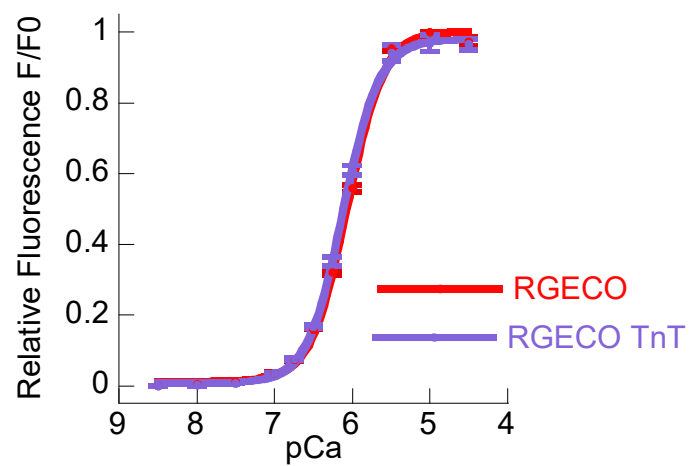

e

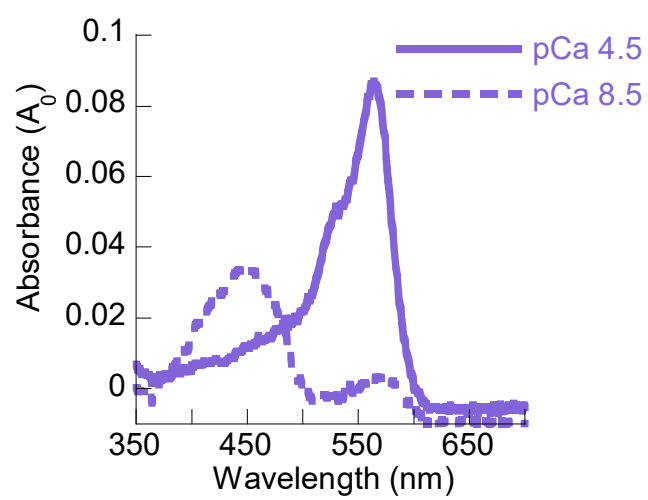

Figure 2. Conjugation of RGECO to the human cardiac TnT does not affect the function of the myofilament, or the indicator. Raptor X predicted structures from full length sequence (Supplementary Figure 13) submitted, returns all amino acid sequence of RGECO conjugated to amino acids 1-10 and 187-288 of human cardiac troponin T including the Gly-Ser linker. This indicates the $\mathrm{C}$ terminal $\mathrm{T} 2$ head thought to be essential for Tn reconstitution was freely available for interaction with the remaining Tn subunits (a). Myofilament function was assessed using in vitro actin activated acto-myosin S1 ATPase assays in (b). The $\mathrm{Ca}^{++}$sensitivity of control (unconjugated) troponin complexes (grey lines) were not significantly different to thin filaments reconstituted with RGECO-TnT (purple lines) in paired experiments. $\mathrm{n}=5$ error bars are \pm SEM. The steady state $\mathrm{Ca}^{++}$binding affinity $\left(\mathrm{K}_{\mathrm{d}}\right)$ of purified recombinant RGECO (red lines) was compared to RGECO-TnT (purple lines) was assessed by analysis of the fluorescence/pCa relationship (c). There is no significant difference in the fluorescence/pCa relationship between the two GECIs $(n=4)$, error bars are \pm SEM. Steady state fluorescence excitation, emission (peak excitation $($ Ex $)=564 n m) /$ peak emission $(E m)=581 \mathrm{~nm}$ ) and absorbance spectra were obtained at pCa8.5 (dotted lines) and 4.5 (solid lines) for purified recombinant RGECO-TnT (d and e). All experiments were performed at $37^{\circ} \mathrm{C}, 1.3 \mathrm{mM} \mathrm{MgCl}_{2} \mathrm{pH}$. 3. Resultant molar extinction co-efficient, quantum yield, brightness and dynamic range measurements are given in Supplementary Table 2. 
bioRxiv preprint doi: https://doi.org/10.1101/268003; this version posted April 16, 2018. The copyright holder for this preprint (which was

a

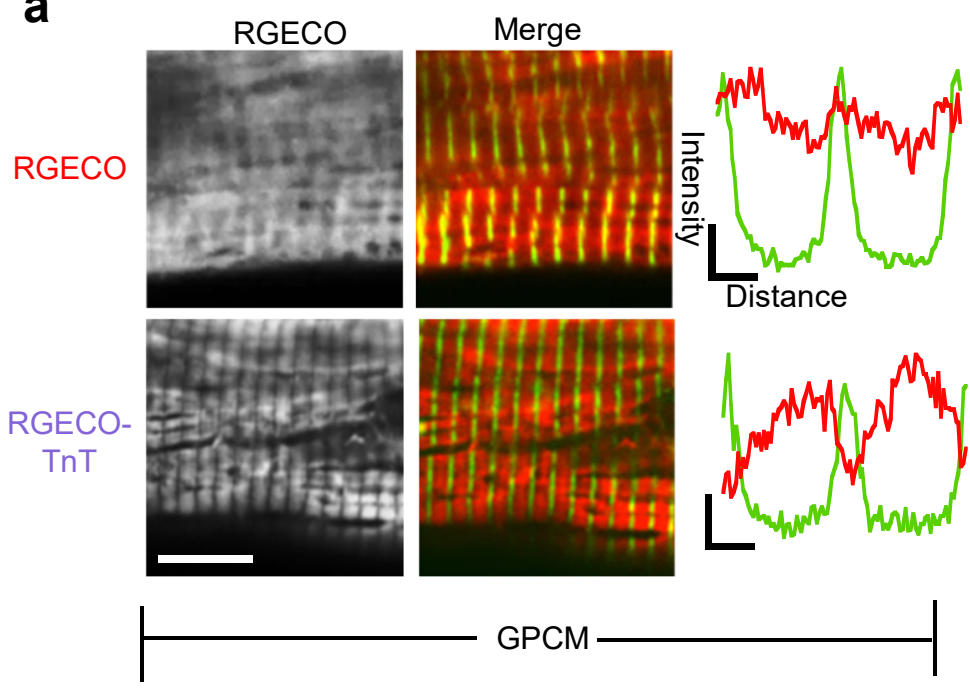

b
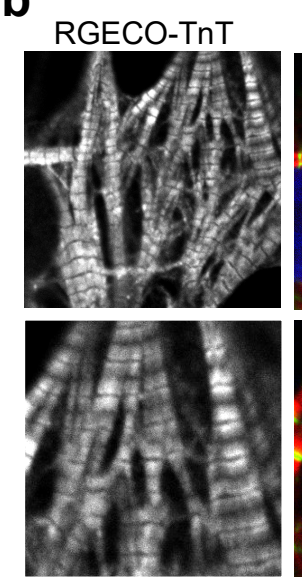

1

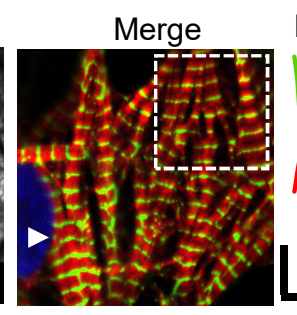

Perinuclear

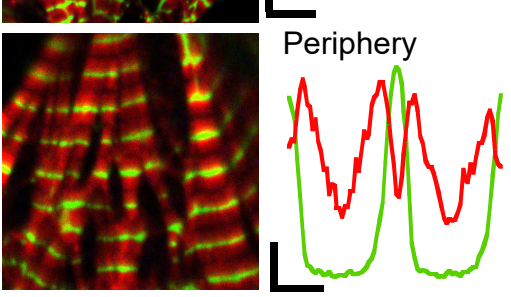

iPS-CM
C

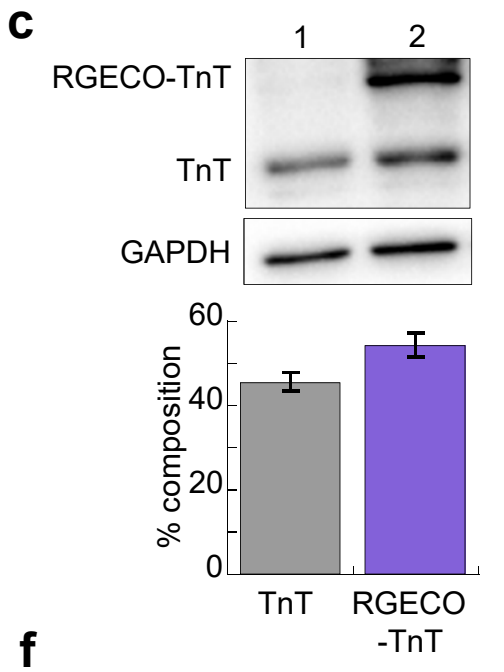

f

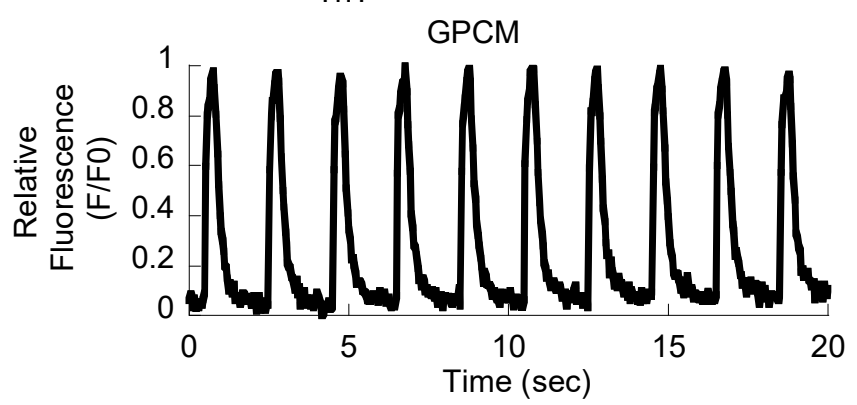

d

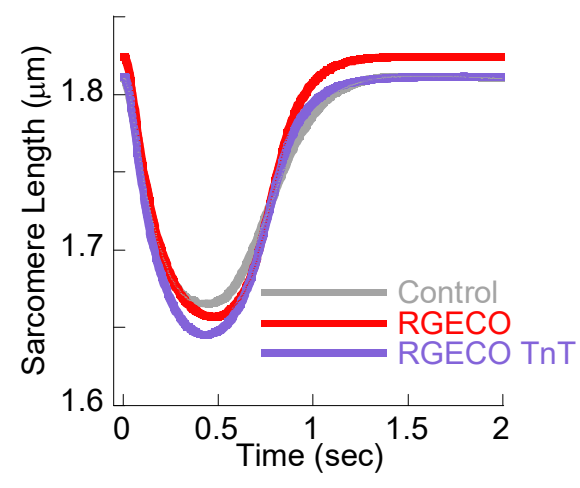

e

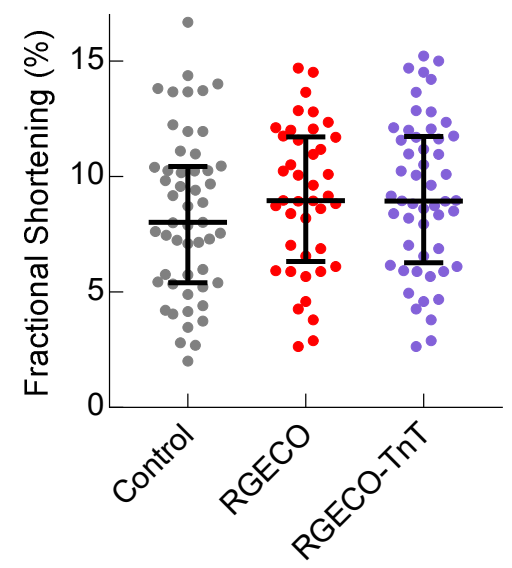

iPS-CM

g

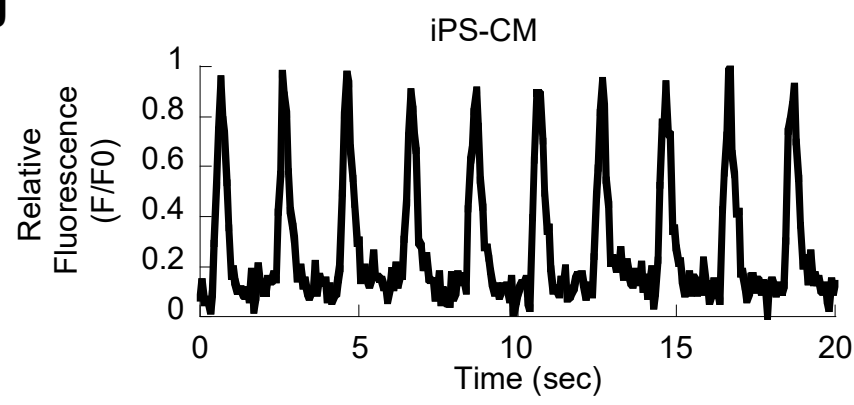

Figure 3. The red genetically encoded $\mathrm{Ca}^{++}$sensor RGECO can be delivered to the myofilament by Troponin- $\mathrm{T}$ fusion revealing a dynamic signal from the sarcomere of adult ventricular and iPS derived cardiomyocytes without affecting contractility. In contrast to the diffuse staining of RGECO, adenovirally expressed RGECO-TnT localises to the I band in confocal microscopy of fixed adult ventricular (a) and human iPS derived cardiomyocytes (b); z disks are revealed by $\alpha$-actinin staining which is green in the merge image. Scale bar $=10 \mu \mathrm{m}$. Dashed box shows the region expanded in the zoom panel. Intensity profile plots spanning two sarcomeres (three z-discs, $\sim 3.6 \mu \mathrm{m}$ ) are shown adjacent to the merge image, $\alpha$-actinin (green line) labels the z-disc, the $\mathrm{Ca}^{++}$indicator (red) is excluded from the Z-disc by TnT fusion. iPS-CMs appear to have different sarcomere morphologies adjacent to the nucleus (white arrow head), or the periphery (zoom panel). Western blot analysis of vGPCMs expressing RGECO-TnT in (c), indicates that $54.3 \pm 5.5 \%(\mathrm{n}=5)$ of endogenous $\mathrm{TnT}$ is replaced. Unloaded sarcomere shortening during electrical paced $(0.5 \mathrm{~Hz})$ of isolated adult cardiomyocytes was used to test cardiac contractile function in vGPCMs by sarcomeric length measurement during contraction (d) or by fractional shortening assessment (e). RGECO (Red) and RGECO-TnT (Purple) infected cells were not significantly different to control (Grey) (e), error bars are \pm interquartile range. The trace recordings of change in red fluorescence $\mathrm{Ca}^{++}$signal acquired from RGECO-TnT expressing single vGPCMs (f) and iPSCMs (g) imaged at video rate during $0.5 \mathrm{~Hz}$ electrical pacing. 
bioRxiv preprint doi: https://doi.org/10.1101/268003; this version posted April 16, 2018. The copyright holder for this preprint (which was not certified by peer review) is the author/funder, who has granted bioRxiv a license to display the preprint in perpetuity. It is made available under aCC-BY-NC-ND 4.0 International license.

a

$250 \mathrm{nM}$ MYK-461

$0.5 \mu \mathrm{M}$ Flecainide

b MYK-461
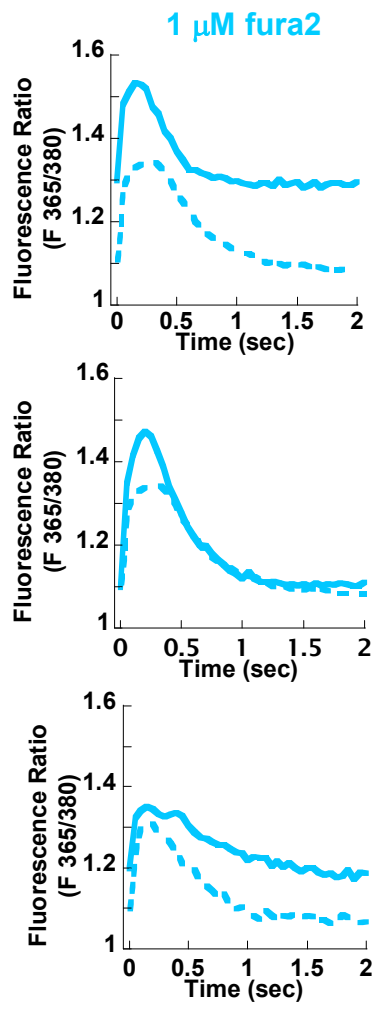

\section{Peak Amplitude Ratio (Control / Treated)}

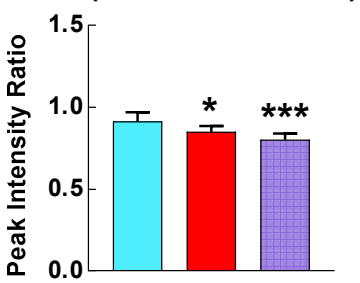

$10 \mu \mathrm{M}$

Levosimendan
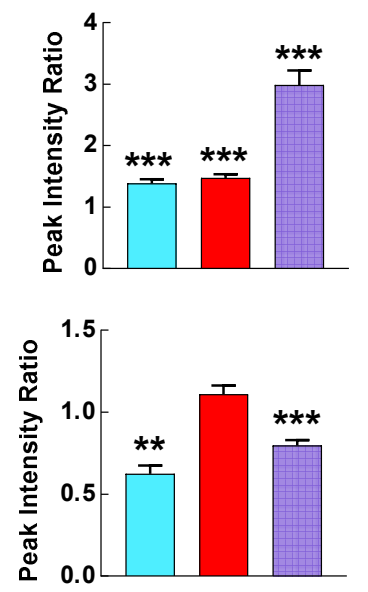

RGECO

RGECO-TnT
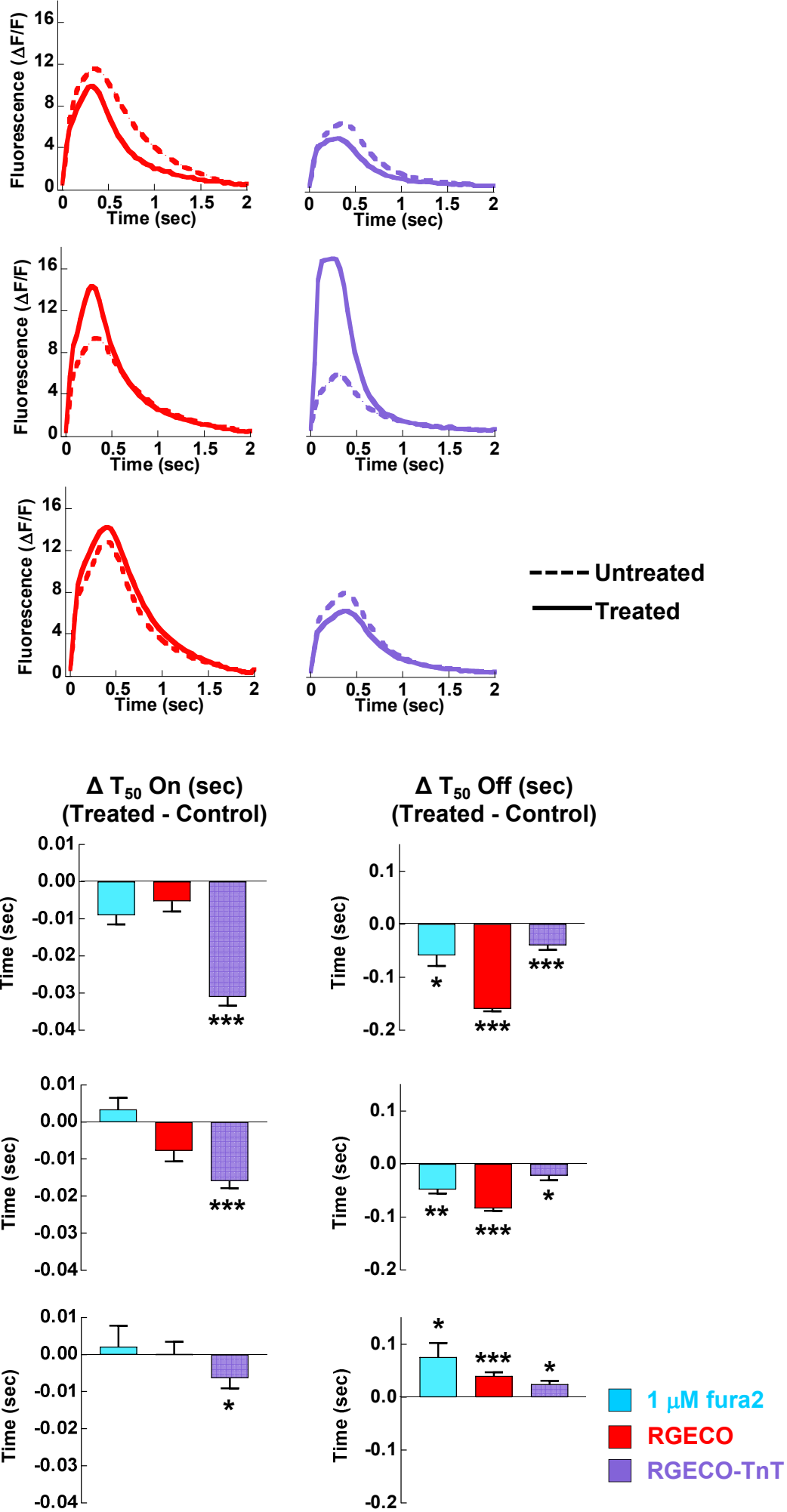

Figure 4. Small molecule effects on paired $\mathrm{Ca}^{++}$transient measurements in vGPCM's are different when fura2 is used compared to a genetically encoded probe RGECO or RGECO-TnT. The effects of MYK-461 (a myosin-ATPase inhibitor that reduces myofilament $\mathrm{Ca}^{++}$sensitivity), Levosimendan (a myofilament $\mathrm{Ca}^{++}$sensitizer) and Flecainide (a sodium channel inhibitor with off target effects on the potassium channel hERG, and the Ryanodine receptor RyR2) on the $\mathrm{Ca}^{++}$transient and contractility were explored in electrically paced $(0.5 \mathrm{~Hz})$ adult cardiomyocytes. The $\mathrm{Ca}^{++}$dependent dynamic signals of $1 \mu \mathrm{M}$ fura2 $\left(\mathrm{F}_{365 / 380}\right)$, RGECO and RGECO-TnT are shown in (a). Each comparison is made in paired experiments between drug treated (solid lines) and DMSO control treated (dashed lines) for fura2 loaded (blue), RGECO infected (red) and RGECO-TnT infected (purple) cells. $\Delta$ values for all extracted parameters (including SEM and $\mathrm{p}$ values) for MYK-461, Levosimendan and Flecainide are plotted in (b). Error bars are SEM, $*=p<0.05, * *=p<0.01$ and $* * *=p<0.001$ using students t-test comparing untreated to treated cells. Absolute numbers for extracted parameters for MYK-461, Levosimendan and Flecainide treatment are tabulated in Supplementary Tables 3, 4 and 5 respectively. 